\title{
МЕЖДУНАРОДНОЕ НАУЧНО-ТЕХНИЧЕСКОЕ СОТРУДНИЧЕСТВО СТРАН-НАБЛЮДАТЕЛЕЙ АРКТИЧЕСКОГО СОВЕТА И РОССИИ В КОНТЕКСТЕ ИЗУЧЕНИЯ АРКТИКИ: ТЕОРЕТИКО-ПРАВОВЫЕ ВОПРОСЫ "
}

\author{
(c) 2021 Ершова Ирина Владимировна \\ Высшая школа экономики, управления и права, доцент кафедры теории и истории государства \\ и права, доцент, кандидат философских наук \\ Северный (Арктический) федеральный университет имени М. В. Ломоносова, Россия, Архангельск \\ E-mail: i.ershova@narfu.ru
}

\section{(c) 2021 Чертова Надежда Андреевна}

проректор по административной и правовой работе, профессор, доктор юридических наук, Высшая школа экономики, управления и права, заведующая кафедрой финансового права и правоведения, доктор юридических наук, профессор

Северный (Арктический) федеральный университет имени М. В.Ломоносова, Россия, Архангельск

E-mail: n.chertova@narfu.ru

\section{(c) 2021 Богданова Елена Николаевна}

Гуманитарный институт, доцент кафедры экономики и менеджмента, доцент, кандидат экономических наук

Филиал Северного (Арктического) федерального университета имени М. В. Ломоносова в г. Северодвинске Архангельской области, Россия

E-mail: e.n.bogdanova@narfu.ru

(c) 2021 Жура Светлана Егоровна

Высшая школа экономики, управления и права, доцент кафедры финансового права и правоведения, доцент, кандидат экономических наук

Северный (Арктический) федеральный университет имени М.В.Ломоносова, Россия, Архангельск E-mail: s.zhura@narfu.ru

\section{(C) 2021 Савельев Иван Вячеславович}

Высшая школа экономики, управления и права, заведующий кафедрой международного права и сравнительного правоведения, кандидат исторических наук, доцент

Северный (Арктический) федеральный университет имени М. В.Ломоносова, Россия, Архангельск E-mail: i.savelev@narfu.ru

\section{(C) 2021 Тетерин Александр Викторович}

Высшая школа экономики, управления и права, доцент кафедры конституционного и муниципального права, кандидат юридических наук

Северный (Арктический) федеральный университет имени М. В.Ломоносова, Россия, Архангельск E-mail: a.teterin@narfu.ru

Статья посвящена рассмотрению теоретических вопросов международного научно-технического сотрудничества на примере взаимодействия стран-наблюдателей Арктического совета и России в контексте изучения Арктики. Анализируется правовая, институциональная и инструментальная сфера межгосударственного сотрудничества в сфере науки и технологий. Делается вывод о России, как перспективном партнере для государств-наблюдателей Арктического Совета международного научно-технического сотрудничества в арктических исследованиях.

Ключевые слова: международное научно-техническое сотрудничество, Арктика, странынаблюдатели Арктического Совета

\footnotetext{
* Исследование выполнено при финансовой поддержке РФФИ в рамках научного проекта № 18-29-15055 мк Разработка правовой модели международного научно-технического сотрудничества в сфере комплексного изучения Арктики
} 
Международное научно-техническое сотрудничество определяется в научной и справочной литературе как вид совместной научной и научно-технической деятельности на уровне государств, правительств, ведомств, регулируемый соглашениями о научно-техническом сотрудничестве. Данная деятельность осуществляется как научными организациями, общественными объединениями ученых, так и отдельными исследователями, и специалистами разных стран, финансируемая из средств государственного бюджета, а также при поддержке государственных и негосударственных фондов.

Для укрепления международного сотрудничества используются такие инструменты, как заключение договоров, соглашений, производится обмен нотами о продлении международного научно-технического сотрудничества. Основной целью заключения международных соглашений является гармонизация интересов разных стран в соответствии со стратегическими направлениями развития внешней и внутренней политики государств в различных сферах жизнедеятельности общества.

Арктика рассматривается как уникальная сфера для международного сотрудничества, в том числе и в сфере научно-технического сотрудничества и является центром притяжения для проведения разнообразных исследований. Ученые многих стран фокусируют свое внимание на вопросах, связанных с экологией, биомониторингом, комплексной безопасностью, на что указывается в разработанных стратегиях освоения Арктики. Необходимость правового регулирования научно-технического сотрудничества с целью гармонизации действий стран по освоению Арктики очевидна, о чем свидетельствует большое количество разработанных и опубликованных на сайте Европейского Союза документов. Для согласования своих стратегий по комплексному освоению Арктики государствам целесообразно объединять свои усилия в сфере научно-технического сотрудничества.

Одной из площадок, на которой страны могут обсуждать свое взаимодействие в контексте Арктики, является Арктический Совет. Странычлены Арктического совета и государстванаблюдатели в своем видении арктической политики выделяют приоритетные сферы: экологию, комплексную безопасность, международное научно-техническое сотрудничество. Для реализации представленной в документах политики страны используют ряд инструментов, среди которых красной нитью выделяется вопрос финансирования посредством грантовой поддержки (Горизонт 2020, Горизонт Европа), путем реализации исследований, финансируемых из средств межстрановых зеркальных фондов.

Большинство стран ЕС присутствуют в Арктическом Совете в качестве наблюдателей. Так, Великобритания имеет статус наблюдателя с 1998 года, активно участвует в заседаниях рабочих групп и осуществляет финансирование арктических проектов. Сфера интересов Великобритании в Арктике корреспондирует общеевропейским: международное научно-техническое сотрудничество, экология, социальные вопросы, а также развитие северного морского пути и энергетической инфраструктуры [4]. На уровне Правительства Великобритании разработаны два основополагающих документа относительно арктической политики: «Адаптация к изменению политики Великобритании в отношении Арктики» 2013 г. и «По ту сторону льда: арктическая политика Великобритании» 2018 г. В указанных документах наука рассматривается в качестве инструмента в сфере дипломатии, политики, а также сотрудничества с арктическими государствами. Для реализации своих научных интересов у Великобритании есть все необходимые условия: в арктические исследования поступают инвестиции как со стороны правительства, так и негосударственных фондов. Инструментами международного научно-технического сотрудничества выступают исследовательские станции, научно-исследовательские суда, самолеты, спутники и др. Все это указывает на возможность проведения сложных и комплексных исследований в арктическом регионе и обнародования результатов исследований в научных статьях. В докладе «По ту сторону льда: арктическая политика Великобритании» подчеркивается важность сотрудничества Великобритании и России в сфере науки. В документе отмечается, что три страны, США, Россия и Канада имеют большее количество публикаций по арктическим исследованиям, нежели Великобритания. Основные каналы сотрудничества в сфере науки между Великобританией и Россией проходят через Британскую научно- инновационную сеть (SIN), которая содействует реализации академических обменов, организации мероприятий, освещающих результаты британской науки и 
техники. Для развития международного научнотехнического сотрудничества в Великобритании создана развитая инфраструктура научных институтов, центров, станций, государственных и негосударственных фондов.

Германия входит в список государствнаблюдателей Арктического совета с 1998 года и имеет достаточно ярко выраженную и активную позицию в арктическом регионе. Круг арктических интересов страны достаточно обширный: сфера экологии, изменение климата, экономики, транспортная, энергетическая и сырьевая безопасность и многое другое [5]. Потенциал государства в сфере международного научно-технического сотрудничества лучше всего раскрывается через ведение совместных проектов. Так, одним из ведущих проектов является российско-германская лаборатория по проведению международных экспедиций и по изучению экосистем в Арктике. В 2019-2020 гг. были одобрены три гранта (сумма грантов - 20 млн. рублей и эквивалентная сумма с немецкой стороны), направленные на изучение климата в Арктике. Германия, как и большинство европейских государств, реализует проекты в рамках программ Эразмус Плюс, Горизонт 2020, а также посредством зеркальных грантов, курируемых научными фондами. Проведение совместных с Российской Федерацией исследований финансируется через программу DAAD, Российский научный фонд совместно Немецким научноисследовательским сообществом - DFG и с Объединением им. Гельмгольца. Таким образом, взаимодействие происходит на уровне софинансирования фундаментальных научных и поисковых научных исследований международными научными коллективами.

Франция получила статус наблюдателя в 2000 году в Арктическом совете. Государство сформировало национальную дорожную карту по Арктике - «Великий Вызов Арктики. Национальная Дорожная карта для Арктики» в 2016 г. Документ определяет и координирует приоритеты Франции в отношении Арктики. В дорожной карте представлены четыре направления, по которым Франция выстраивает арктическую политику: во-первых, определены национальные интересы в Арктике в сфере экономики, науки, обороны и.п.); во-вторых необходимым условием представляется повышение легитимности Франции в арктических делах и форумах; в-третьих, акцент ставится на работу по обеспечению баланса между национальными интересами и общими интересами в управлении Северным Ледовитым океаном; и, в-четвертых, определено направление по охране окружающей среды [7]. Очевидно, что научная составляющая является одним из ключевых направлений в выстраивании международного научно-технического сотрудничества. Для продвижения и развития науки во Франции наличествует развитая инфраструктура научных учреждений, фондов, исследовательских баз. В тексте дорожной карты Франция выражает интерес к сотрудничеству с Россией в области энергетики (нефть и газ) и науки. Одним из крупнейших российскофранцузских грантов, финансированных РФФИ являлся «CARERS», поддерживающий исследования в сфере изменения климата. На постоянной основе проводятся совместные конкурсы на получение грантов РНФ по проведению фундаментальных научных исследований и поисковых научных исследований международными научными коллективами совместно с Национальным исследовательским агентством Франции - ANR. Таким образом, Франция, обладая доставочными ресурсами для проведения научных исследований, занимает свою нишу в международном научно-техническом сотрудничестве.

Среди неарктических государств, имеющих статус наблюдателя в Арктическом совете с 1989 года, следует назвать Нидерланды. На государственном уровне сформирована арктическая стратегия, заключенная в документ «Полярная стратегия Нидерландов. Готовность к изменениям» разработанная на период 2021-2025 гг. [8]. В программу отдельными разделами включены положения, касающиеся Арктики, Антарктиды и вопросов имплементации программы посредством проведения исследований на базе инфраструктурных объектов. В части проведения исследований выбраны приоритетные направления, такие как социальная сфера, вопросы экологии и биоразнообразия. На сайте Министерства иностранных дел Российской Федерации представлено совместное заявление Российской Федерации и Королевства Нидерландов о сотрудничестве в Арктической зоне Российской Федерации и урегулировании спора [2], согласно которому указывается на важность проведения совместных исследований в Арктической зоне РФ путем проведения совместных экспедиций. В основном, межстрановое сотрудничество в научно-технической сфере осуществляется в 
сфере высшего образования. Правовое регулирование международного научно-технического сотрудничества между Нидерландами и Россией осуществляется на основе Меморандума о взаимопонимании между Министерством образования и науки Российской Федерации и Министерством образования, культуры и науки Нидерландов (08.04.2013 г.). Основными направлениями взаимодействия в рамках международного научно-технического сотрудничества являются нанотехнологии, генетика и биотехнологии, информационно-коммуникационные технологии, экология и проблемы глобального изменения климата, ядерная физика, транспортные и космические системы. Так, на сайте Министерства науки и высшего образования Российской Федерации указывается, что в рамках межуниверситетского сотрудничества университеты Российской Федерации реализуют 24 образовательные программы с университетами Королевства Нидерланды, 10 из которых ведут к получению двойного диплома, в том числе 9 из них реализуются на английском языке, а 62 университетами России заключено 174 совместных соглашений с 107 нидерландскими организациями. Особый интерес был выражен в сотрудничестве в сфере цифровизации, социальных и гуманитарных наук, сельского хозяйства, изучения новых материалов и композитов, а также энергетики и транспорта, создания геномных центров и других [1].

Швейцария является наблюдателем в Арктическом совете относительно недавно, с 2017 года. Швейцария не разработала отдельного документа, где прописывалась бы арктическая стратегия государства. Швейцарское научное сообщество достигает реализации междисциплинарных целей в рамках международного сотрудничества путем реализации международных научных программ и активного участия в неправительственных организациях, таких как Научный комитет по антарктическим исследованиям и Международный Арктический научный комитет. Швейцария активно участвует в различных международных арктических проектах, примером одного из них может служить международная экспедиция «Арктика 2021» (05.08.2021 г.-06.09.2021 г.), целью которой являлся сбор данных для исследования изменения климата в высоких широтах и особенностью которой является совмещение морских и береговых исследований. Во время международной экспедиции были проведены комплексные исследования состояния природной среды в условиях изменяющегося климата [3]. Экспедиция организована Арктическим и антарктическим научно-исследовательским институтом Росгидромета (ААНИИ) совместно со Швейцарским Полярным Фондом. Таким образом, при межинституциональном софинансировании становится возможным проведение арктических исследований посредством участия в международных исследовательских группах, что может быть рассмотрено как один из механизмов укрепления международного научно-технического сотрудничества. На постоянной основе проводятся заседания Смешанной российско-швейцарской комиссии по научно-техническому сотрудничеству. Между Швейцарией и Российской Федерацией подписаны соглашения по сотрудничеству в области наук о Земле, ядерных исследований, станкостроения, машиностроения, материаловедения медицины и иные. В сфере международного научно-технического сотрудничества акцент ставится на организацию совместных конкурсов научно-исследовательских проектов. В апреле 2019 года было подписано Соглашение между Правительством Российской Федерации и Европейской организацией ядерных исследований (CERN) о научно-техническом сотрудничестве в области физики высоких энергий и иных сферах взаимного интереса и Протокол к нему. Соглашение позволяет развивать многостороннее сотрудничество российских и швейцарских учёных и специалистов в рамках указанной организации. В ноябре 2019 г. Указом Президента РФ соглашение было ратифицировано [1].

Польша располагает разветвлённой исследовательской инфраструктурой, включая центр полярных исследований, экспедиционные базы, исследовательские станции, в том числе исследовательским судном «Океания», «Горизонт II» которые используются для исследовательских экспедиций в европейской Арктике. Польша является активным участником в международном научном сотрудничестве в Арктике через различные сети (такие, как, SAON, EU-Polarnet, BOREAS) и исследовательские проекты во многих арктических науках и дисциплинах, а также является страной-наблюдателем Арктического совета с 1998 года. Основополагающим документом, содержащим видение арктической политики Польши, является национальная программа полярных исследований на 2017-2027 гг. 
«Стратегия польских полярных исследованийконцепция на 2017-2027 годы”. Польша активно ангажирована в работу научных комитетов, ассоциаций, однако, на данный момент с Россией научно-исследовательские проекты по арктическим тематикам отсутствуют.

Италия является страной-наблюдателем в Арктическом совете с 2013 года, и имеет достаточно развитую инфраструктуру для имплементации основных положений международного научно-технического сотрудничества в сфере изучения Арктики. В документе «К итальянской стратегии в Арктике» [9] прописаны основные направления, среди которых указывается на необходимость научно-технического сотрудничества, изучения изменений климата, экономика. Для осуществления заложенных в документе идей Италия располагает хорошо развитой институциональной сферой научных организаций, фондов, исследовательских баз. Относительно российско-итальянского международного научно-технического сотрудничества следует отметить, что оно достаточно удачно осуществлялось в рамках научно-исследовательских зеркальных грантов РФФИ и Национальным исследовательским советом Италии, проводимым в сфере медицины и естественных наук, энергетики. В рамках двустороннего сотрудничества с Италией, как правило, объявляются конкурсы по приоритетным направлениям прикладных научных исследований: аэрокосмические исследования, науки о жизни, энергетика и окружающая среда, астрофизика, физика и прикладная физика, химия, математика, науки о Земле.

Испания является наблюдателем в Арктическом совете с 2006 года. Испания сформулировала основные идеи арктической политики в документе «Принципы испанской полярной стратегии». Официальная политическая позиция Испании исходит из того, что полярные исследования - как в Антарктике, так и в Арктике - имеют решающее значение для изучения практически всех наук, в том числе и экологических [6]. Испания располагает сетью научноисследовательских институтов, центров, баз, а также судном «Гесперидос». Относительно сотрудничества с Россией, Испания проявляет интерес в сфере энергоресурсов. Одной из наиболее развитых сфер сотрудничества является образовательная, в рамках которой подписано соглашение о взаимном признании образования, квалификаций и ученых степеней. Подписанное соглашение позволяет активизировать мобильность студентов, преподавателей и ученых, что будет содействовать развитию межстрановых отношений в научно-техническом сотрудничестве.

Итак, для проведения арктических исследований в странах ЕС, имеющих статус наблюдателей в Арктическом Совете, есть все необходимые ресурсы: нормативные акты, исследовательские станции, научно-исследовательские базы, центры. Финансирование исследовательской деятельности проводится, как правило, на уровне государственного финансирования и через негосударственные фонды. Россия рассматривается как перспективный партнер для стран ЕС в контексте арктических исследований в части исследования изменения климата и окружающей среды. Помимо указанного направления, приоритетными определяются такие, как авиация, энергетика, продовольствие, сельское хозяйство, биотехнологии, здравоохранение, исследования в области ИКТ, мобильность, нанотехнологии, исследовательская инфраструктура, космические исследования.

\section{Библиографический список}

1. Министерство науки и высшего образования Российской Федерации [Электронный ресурс] Режим доступа: https://minobrnauki.gov.ru/press-center/news/? ELEMENT_ID=21952 (дата обращения:02.11.2021 г.).

2. Совместное заявление Российской Федерации и Королевства Нидерландов о сотрудничестве в Арктической зоне Российской Федерации и урегулировании спора [Электронный ресурс] Режим доступа: https:// www.mid.ru/ru/maps/nl/-/asset_publisher/dPPQX1ysEV4N/content/id/3651941 (дата обращения: 02.11 .2021 г.).

3. Стартовала международная экспедиция по исследованию арктических морей и островов «Арктика - 2021» [Электронный ресурс] Режим доступа: https:/www.meteorf.ru/press/news/25414/ (дата обращения 02.11.2021 г.).

4. Beyond the Ice UK policy towards the Arctic [Электронный ресурс] Режим доступа: https://assets.publishing. service.gov.uk/government/uploads/system/uploads/attachment_data/file/697251/beyond-the-ice-uk-policytowards-the-arctic.pdf (дата обращения: 02.11.2021 г.). 
5. Germany’s Arctic Policy Guidelines [Электронный ресурс] Режим доступа: https://www.arcti office.de/fileadmin/ user_upload/www.arcticoffice.de/PDF_uploads/Germany_s_Arctic_Policy_Guidelines_2019_Web.pdf (дата обращения: 02.11.2021 г.).

6. Guidelines for a Spanish Polar Strategy [Электронный ресурс] Режим доступа: https://www.thearcticinstitute. org/countries/spain/ (дата обращения:02.11. 2021 г.).

7. The great CHALLENGE OF THE ARCTIC National Roadmap for the Arctic [Электронный ресурс] Режим доступа: https://www.diplomatie.gouv.fr/IMG/pdf/frna_-_eng_-interne_-_prepa_-_17-06-pm-bd-pdf_cle02695b.pdf (дата обращения: 02.11.2021 г.).

8. The Netherlands' Polar Strategy 2021-2025 [Электронный ресурс] Режим доступа: https://d2k0ddhflgrk1i. cloudfront.net/CiTG/Actueel/Test/NPP_2021_2025_WEB_compr.pdf (дата обращения: 02.11.2021 г.).

9. TOWARDS AN ITALIAN STRATEGY FOR THE ARCTIC [Электронный ресурс] Режим доступа: https://www.esteri. it/mae/resource/doc/2019/12/towards_an_italian_strategy_for_the_arctic_-_national_guidelines.pdf (дата обращения: 02.11.2021 г.). 